\title{
GERAKAN PEDULI COVID-19 DI LINGKUNGAN KAMPUS STIKES CENDEKIA UTAMA KUDUS
}

\author{
David Laksamana Caesar ${ }^{1}$, Rochmatun Nafi'ah ${ }^{2}$, Lilis Sugiarti ${ }^{3}$ \\ ${ }^{1}$ Prodi S1 Kesehatan Masyarakat, ${ }^{2}$ Prodi S1 Farmasi, ${ }^{3}$ Prodi D3 Farmasi \\ STIKES Cendekia Utama Kudus \\ caesar.david77@gmail.com
}

\begin{abstract}
ABSTRAK
Dunia saat ini sedang dilanda pandemi, begitu pula Indonesia. Covid-19 merupakan penyakit baru yang mulai masuk ke Indonesia pada bulan Maret 2020. Saat ini penyakit ini telah menyebabkan ribuan kematian penduduk Indonesia dan ribuan orang lain yang mengalami kesakitan. Dampak covid-19 tidak hanya pada aspek kesehatan, namun juga bedampak pada aspek lain yaitu pendidikan dan ekonomi. Masyarakat mulai kehilangan mata pencaharianya, dan turunya daya beli masyarakat. Metode pelaksanaan kegiatan pengabdian masyarakat ini adalah dengan 1) Pembuatan Hand Sanitizer dan Hand Wash,2) Pendistribusian Hand Sanitizer dan Hand Wash ke masyarakat sekitar kampus, 3) Pembagian sembako kepada masyarakat. STIKES Cendekia Utama Kudus sebagai bagian tidak terpisahkan dari masyarakat berusaha mengambil peran dalam menangani dampak dari penyakit ini. Melalui kegiatan pengabdian masyarakat dalam bentuk gerakan peduli covid-19 ini harapanya bisa sedikit meringankan beban masyarakat dalam menghadapi covid-19. Selain itu, pemberian edukasi tentang covid-19 kepada masyarakat harapanya dapat menjadi tambahan informasi bagi masyarakat di tengah pandemi covid-19 yang sampai saat ini masih terus berkembang dan jumlah kasusnya terus naik.
\end{abstract}

Kata Kunci : Peduli, Covid-19

\section{ABSTRACT}

The world is currently hit by a pandemic, and so is Indonesia. Covid-19 is a new emerging disease that began to enter Indonesia in March 2020. Currently this disease has caused thousands of deaths in Indonesians and thousands of other people who are in pain. The impact of Covid-19 is not only on the health aspect, but also on other aspects, is education and the economy. People are starting to lose their livelihoods, and people's purchasing power has decreased. The method of implementing this community service activity is by 1) Making Hand Sanitizers and Hand Washes, 2) Distributing Hand Sanitizers and Hand Washes to communities around the campus, 3) Distribution of basic necessities to the community. STIKES Cendekia Utama Kudus as an integral part of the community tries to take role in dealing with the effects of this disease. Through community service activities in the form of a covid-19 care movement, he hopes that it can slightly lighten the burden on the community in facing Covid-19. In addition, 
providing education about covid-19 to the public is hoped to be additional information for the public in the midst of the Covid-19 pandemic which is still growing and the number of cases continues to rise

Keywords : Care, Covid-19 


\section{PENDAHULUAN}

Saat ini dunia sedang digemparkan dengan adanya wabah penyakit baru (new emerging disease). Penyakit ini disebabkan oleh sebuah virus dan dinamakan Coronavirus Disease 2019 (covid-19). Covid-19 adalah penyakit menular yang disebabkan oleh Severe Acute Respiratory Syndrome Coronavirus 2 (SARS-Cov-2). SARS-Cov-2 merupakan coronavirus jenis baru yang belum pernah di identifikasi sebelumnya pada manusia. [1]

Infeksi covid-19 dapat menimbulkan gejala ringan, sedang, dan berart. Gejala klinis utama yang muncul yaitu demam (suhu $>38^{\circ} \mathrm{C}$ ), batuk, dan kesulitan bernapas. Selain itu, dapat disertai dengan sesak memberat, fatigue, mialgia, gejala gastroinstestinal seperti diare dan gejala saluran napas lain. Setengah dari pasien timbul sesak dalam satu minggu. Pada kasus berat perburukan secara cepat dan progresif seperti ARDS, syok septic, asidosis metabolic yang sulit dikoreksi dan perdarahan atau disfungsi system koagulasi dalam beberapa hari. Pada beberapa orang gejala muncul ringan, bahkan tidak disertai dengan demam. [2]

Kasus pertama penyakit ini terjadi di Wuhan China. WHO melaporkan kasus pneumonia yang tidak diketahui etiologinya di Kota Wuhan, Provinsi Hubei, Cina pada tanggal 7 Januari 2020. China mengidentifikasi kasus tersebut sebagai jenis baru dari coronavirus. Kemudian pada tanggal 11 Maret 2020 WHO menetapkan Covid-19 sebagai pandemic internasional. [1]

Sebanyak 216 negara terinfeksi virus corona. Menurut data WHO per tanggal 10 Agustus 2020 jumlah penderita 17.660.523 terinfeksi Covid-19, dengan kasus meninggal 680.894 orang. Di Indonesia pun sampai bulan Agustus total kasus terinfeksi 125.396 orang. Angka kematian mencapai 5.723 dengan angka kesembuhan 80.952 orang. [3] Pasien terkonfirmasi Covid-19 di Indonesia berawal dari suatu acara di Jakarta dimana 
penderita kontak dengan soerang warga Negara asing (WNA) asal Jepang yang tinggal di Malaysia. [4]

Jawa Tengah menempati posisi ketiga nasional kasus positif covid19 yang telah terkonfirmasi. Kasus covid-19 tercatat sudah mencapai 10.611 kasus positif. Jumlah ini menyumbang 8,5\% dari angka kasus terkonfirmasi nasional. [3] Di Jawa Tengah sendiri muncul konsep Jogo Tonggo yang telah digalakan oleh Bapak Gubernur Jawa Tengah sejak awal ditetapkanya Covid-19 sebagai bencana nasional. Sehingga seluruh lapisan masyarakat diharapkan ikut berpartisipasi dalam mencegah berkembangnya Covid-19 di masyarakat.

Kota Semarang masih menempati posisi pertama dalam kasus Convid-19 terkonfirmasi di Jawa Tengah, sedangkan Kabupaten Kudus menempati posisi keempat setelah Kabupaten Jepara, dan Kabupaten Demak. Sampai bulan Agustus ini terkonfirmasi tedapat 799 kasus Covid19 di Kabupaten Kudus. Kasus meninggal 94 orang dan kasus sembuh tercata 414 orang. [5]

Pemerintah Kabupaten Kudus melalui Tim Gugus Covid-19 Kabupaten Kudus sudah secara aktif melakukan sosialisasi kepada masyarakat melalui berbagai macam media baik cetak maupun elektronik. Harapanya angka kasus covid-19 di Kabupaten Kudus berangsur-angsur turun dan Kabupaten Kudus masuk dalam kategori daerah hijau.

Pandemi covid-19 ini juga berdampak sangat signifikan kepada perekonomian dan kesejateraan masyarakat Kabupaten Kudus. Banyak industry yang melakukan pemutusan hubungan kerja, dan beberapa UKM yang mengalami penurunan omset penjualan, sehingga dari sisi ekonomi masyarakat mengalami kesulitan. Hal ini mendasari kami tim Pengabdian Masyarakat STIKES Cendekia Utama Kudus melakukan kegiatan Gerakan Peduli Covid-19 di Lingkungan Kampus STIKES Cendekia Utama Kudus. Harapanya dengan kegiatan ini masyarakat dapat memperoleh pengetahuan dan gambaran mengenai penyakit covid-19 dan memberikan edukasi kepada masyarakat mengenai personal hygiene 
dalam rangka memutus rantai coivd-19. Dan dampak tidak langsungnya ada semoga kegiatan ini dapat sedikit meringankan beban ekonomi masyarakat ditengah pandemic covid-19.

\section{METODE PELAKSANAAN}

Kegiatan pengabdian kepada masyarakat ini dinamakan Gerakan Peduli Covid-19 di Lingkungan Kampus STIKES Cendekia Utama Kudus. Kegiatan ini merupakan serangkaian kegiatan yang sudah dimulai dari bulan Januari 2020 sampai dengan bulan April 2020. Diawali dengan penggalangan dana peduli covid-19 yang sasaranya adalah civitas akademika kampus. Namun seiring berjalanya waktu, donasi tidak hanya berasal dari civitas akademika, namun beberapa komponen masyarakat juga turut memberikan sumbangsih dalam penggalangan dana ini baik dalam bentuk uang ataupun barang.

Kemudian bantuan yang terkumpul dibelanjakan untuk melakukan beberapa kegiatan pengabdian kepada masyarakat yang terdiri dari : 1) Pembuatan Hand Sanitizer, 2) Pembuatan Hand Wash, 3) Pembuatan face shield, 4) Pendistribusian Hand Sanitizer dan Hand Wash ke masjidmasjid sekitar kampus serta masyarakat sekitar kampus, 5) Pembagian masker, dan 6) Pembagian sembako kepada masyarakat.

Sasaran dari kegiatan pengabdian masyarakat ini adalah masyarakat sekitar kampus, tempat ibadah sekitar kampus, tempat ibadah sekitar kampus dan rumah sakit di Kabupaten Kudus.

\section{HASIL DAN PEMBAHASAN}

Kegiatan pengabdian kepada masyarakat di awali dengan pembuatan hand sanitizer dan hand wash. Hand sanitizer dan hand wash menjadi barang yang langka dan bernilai sangat tinggi saat itu. Sehingga kami, tim pengabdian masyarakat STIKES Cendekia Utama Kudus memutuskan untuk membuat hand sanitizer dan hand wash untuk dibagikan secara gratis kepada masyarakat sekitar kampus. Kami beserta 
mahasiswa membuat keduanya ini selama 2 minggu dengan menggunakan alat dan bahan sebagai berikut :

1. Pembuatan Hand Sanitizer dan Hand Wash

Alat untuk pembuatan hand sanitizer antara lain gelas ukur, labu ukur, batang pengaduk, beaker glass, corong, drigen. Sedangkan untuk bahan yang dibutuhkan antara lain alcohol $96 \%, \mathrm{H}_{2} \mathrm{O}_{2}$, Glycerol, dan Aquadest.

Alat untuk pembuatan hand wash antara lain gelas ukur, batang pengaduk, kompor, panic, corong, beaker glass. Sedangkan bahan yang digunakan texaphone, Mg stearat, Ampitol, Fragnance, dan Aquadest.

2. Pendistribusian Hand Sanitizer dan Hand Wash

Hand Sanitizer dan Hand Wash yang telah dibuat oleh tim bersama mahasiswa berjumlah 36 liter hand sanitizer dan 100 liter hand wash. Kemudian, kami kemas dalam wadah-wadah kecil ukuran $220 \mathrm{ml}$ untuk hand wash sedangkan untuk hand sanitizer kami kemas dalam botol spray ukuran $100 \mathrm{ml}$.

Ukuran-ukuran kecil hand sanitizer dan hand wash kami distribusikan kepada masyarakat sekitar kampus melalui penguruspengurus RT. Sedangkan untuk masjid dan rumah sakit kami distribusikan dalam kemasan yang lebih besar, yaitu ukuran 2 liter.

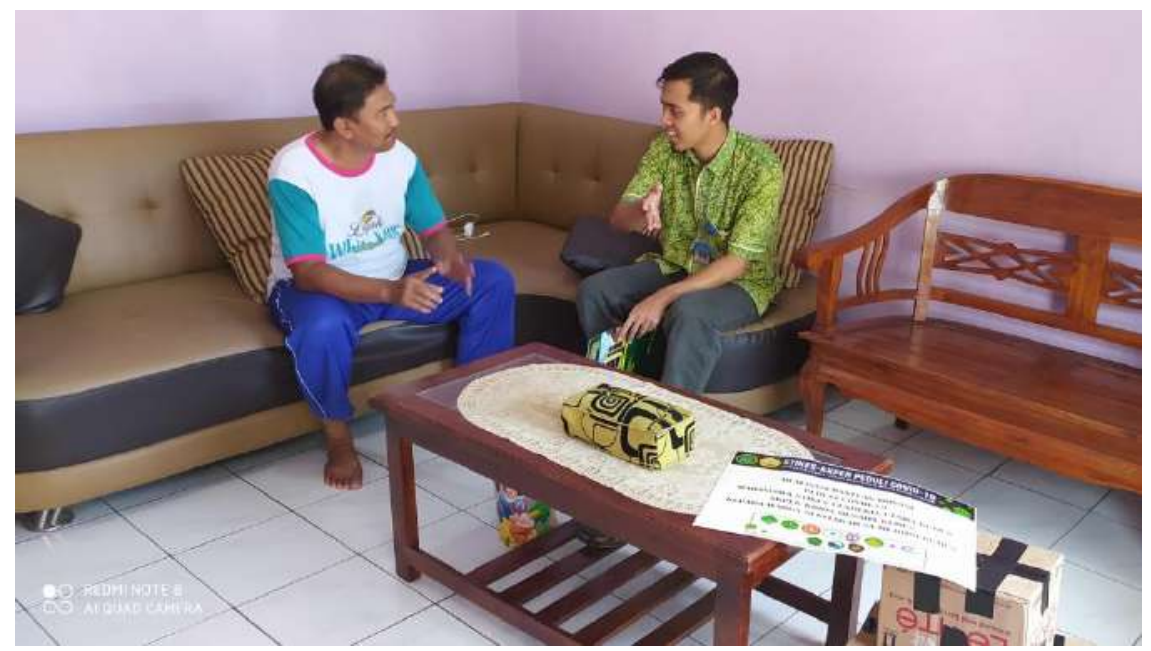

Gambar 1. Edukasi Personal Hygiene kepada masyarakat 
Selain mendistribusikan hand wash dan hand sanitizer kami juga melakukan edukasi secara singkat kepada masyarakat tentang 185andemic covid-19 yang tengah melanda Indonesia khususnya dan dunia pada umumnya. Mulai dari mekanisme penularan penyakit yang menurut Van Doremalen et all dalam Adityo Susilo dkk, bahwa transmisi SARS Cov-2 dari manusia ke manusia terjadi melalui droplet yang keluar saat batuk atau bersin. Selain itu masih menurutnya virus ini dapat hidup di udara selama setidaknya 3 jam. [6] Hal inilah yang mendasari pentingnya pemakaian masker saat keluar rumah dan berinteraksi dengan orang lain.

Edukasi tentang kebersihan personal (Personal Hygiene) menjadi sangat penting dalam rangka memutus rantai penyebaran coivd-19. Salah satu bentuk upaya menjaga kebersihan personal adalah dengan membiasakan diri untuk melakukan cuci tangan. Menurut Fajar Ardi Desiyanto dan Siti Nur Djannah dalam penelitanya menyatakan mencuci tangan menggunakan sabun (hand wash) efektif dalam menurunkan jumlah angka kuman. Begitu pula dengan menggunakan hand sanitizer. Dalam penelitianya Fajar mengatakan hand sanitizer $60 \%$ efektif dalam menurunkan jumlah kuman dibandingkan dengan bahan lain. [7] Kebiasaan mencuci tangan juga merupakan gerakan yang tengah disosialisasikan oleh pemerintah kepada seluruh masyarakat Indonesia. Sehingga tim pengabdian masyarakat dan mahasiswa membuat dan mendistribusikan hand wash dan hand sanitizer ini kepada masyarakat.

Pemberian edukasi merupakan salah satu usaha yang cukup efektif untuk meningkatkan pengetahuan masyarakat. Seperti yang dikutip dalam penelitian David dan Ervi yang mengatakan bahwa pemberian buku saku tentang sanitasi berpengaruh terhadap pengetahuan masyarakat tentang sanitasi lingkungan dengan nilai $p$ value 0,0001 . [8] 


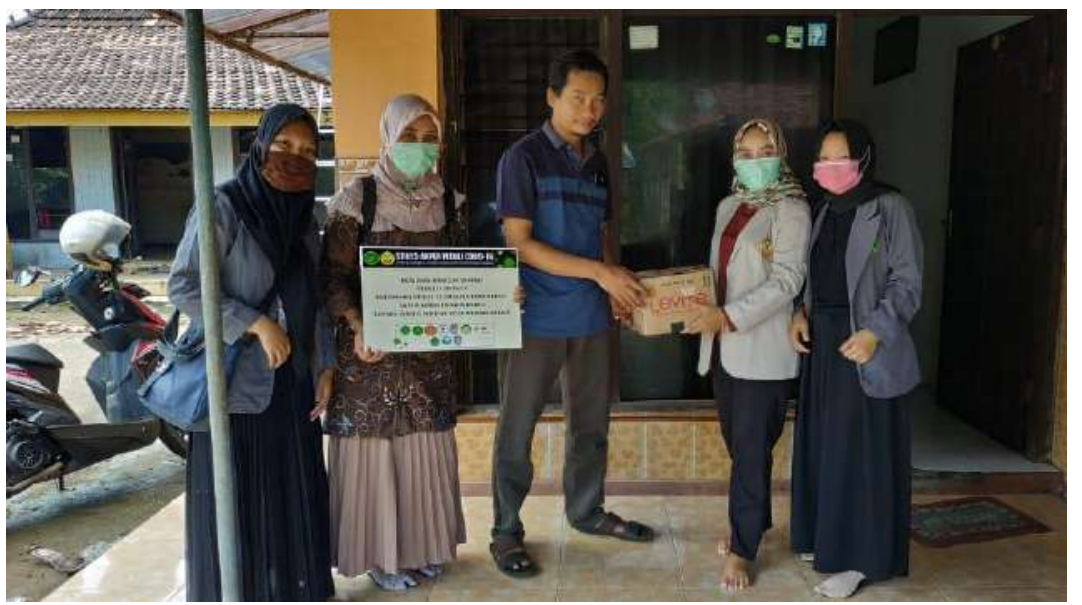

Gambar 2. Pendistribusian Hand Sanitizer dan Hand Wash

3. Pendistribusian Sembako

Kegiatan ketiga yang kami lakukan adalah dengan menyalurkan sembako kepada para pedangan kaki lima dan tukang becak disekitar lingkungan kampus. Total 40 paket sembako yang kami salurkan kepada masyarakat sekitar kampus. Kegiatan ini kami libatkan mahasiswa secara langsung mulai dari pengepakan paket sembako sampai dengan penyaluran bantuan kepada masyarakat.

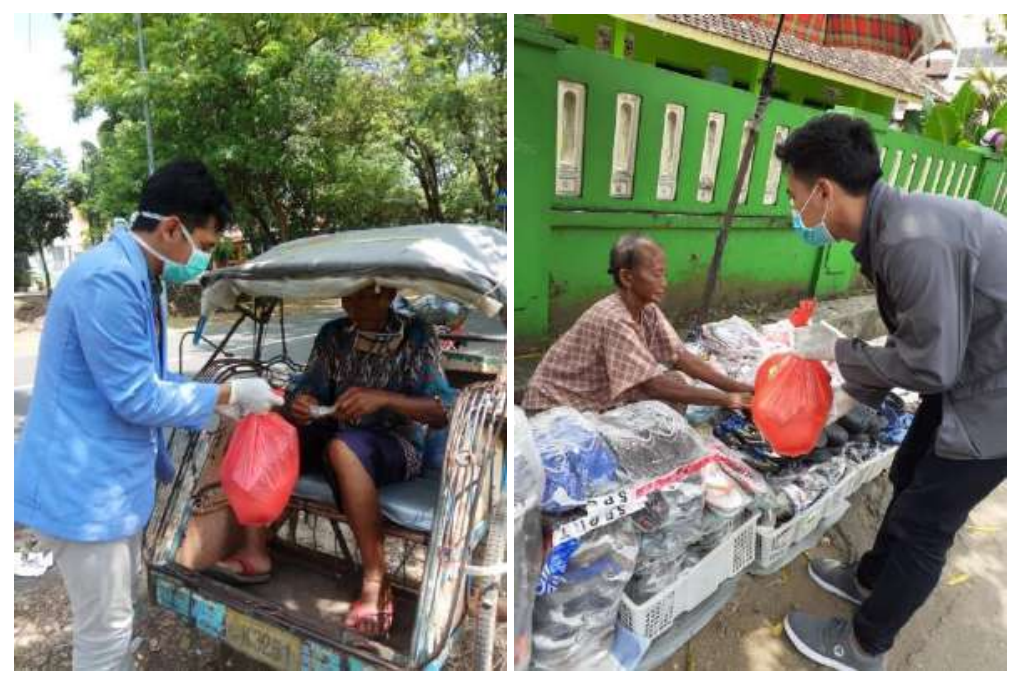

Gambar 3. Pendistribusian paket sembako kepada masyarakat 


\section{SIMPULAN DAN SARAN}

\section{Simpulan}

Kegiatan pengabdian masyarakat yang telah dilakukan di atas merupakan bentuk kecil dari peran kami sebagai bagian dari institusi pendidikan yang berada di tengah masyarakat. Sumbangsih berupa pembuatan produk hand sanitizer dan hand wash merupakan aplikasi dari ilmu pengetahuan dan teknologi (IPTEK) yang bisa dimanfaatkan langsung hasilnya oleh masyarakat. Selain itu, edukasi tentang covid-19 melalui diskusi langsung, diharapkan dapat memberikan bekal kepada masyarakat di tengah-tengah pandemic yang sedang melanda dunia.

\section{Saran}

Perlu kerja bersama dan lintas sector agar masyarakat dapat lebih siap menghadapi pandemi ini. Tidak hanya dari instansi kesehatan dan pendidikan, namun juga bidang yang lain. Karena pandemi covid-19 berdampak tidak hanya pada aspek kesehatan, namun juga ekonomi dan kesejahteraan masyarakat.

\section{DAFTAR PUSTAKA}

1. Menteri Kesehatan. 2020. Pedoman Pencegahan dan Pengendalian Coronavirus Disease (Covid-19) Revisi Ke-5. Jakarta: Kementerian Kesehatan.

2. Perhimpunan Dokter Paru Indonesia. 2020. Panduan Praktik Klinik : Pneumonia 2019-nCov. Jakarta : PDPI.

3. Gugus Covid-19 Indonesia. Data Sebaran Kasus Covid-19 di Indonesia. Di unduh tanggal 10 Agustus 2020 melalui website https://covid19.go.id/

4. WHO. 2020. WHO Director-General's remaks at the media briefing on 2019-nCov on 11 February 2020. Cited Feb 13rd 2020. 
5. Tanggap Covid-19 Provinsi Jawa Tengah. Data Sebaran Kasus Covid19 di Provinsi Jawa Tengah. Di unduh tanggal 10 Agustus 2020 melalui website https://corona.jatengprov.go.id/data.

6. Susilo A, Rumende CM, Pitoyo CW, Santoso WD, Yulianti M, Herikurniawan H, Sinto R, Singh G, Nainggolan L, Nelwan EJ, Chen LK. Coronavirus Disease 2019: Tinjauan Literatur Terkini. Jurnal Penyakit Dalam Indonesia. 2020 Apr 1;7(1):45-67.

7. Desiyanto FA, Djannah SN. Efektivitas mencuci tangan menggunakan cairan pembersih tangan antiseptik (hand sanitizer) terhadap jumlah angka kuman. Jurnal Kesehatan Masyarakat (Journal of Public Health). 2013 Dec 9;7(2).

8. Caesar DL, Dewi ER. Pengaruh Media Buku Saku Terhadap Pengetahuan Tentang Sanitasi Lingkungan Pada Kader Kesehatan Desa Cranggang. JKM (Jurnal Kesehatan Masyarakat) Cendekia Utama. 2018 Aug 28;6(1):137-46. 